\title{
Identification of ectoparasites and endoparasites on fruit bats (Cynopterus brachyotis) in Ketapang Timur Village, Ketapang Sub-District, Sampang District
}

\author{
${ }^{1)}$ Mohamad Safri Sauqi, ${ }^{2)}$ Tjuk Imam Restiadi ${ }^{\circledR},{ }^{3)}$ Setiawan Koesdarto, ${ }^{4}$ Poedji Hastutiek, \\ ${ }^{5)}$ Boedi Setiawan, ${ }^{6)}$ Agus Wijaya \\ ${ }^{1)}$ Student, Faculty of Veterinary Medicine, Airlangga University \\ ${ }^{2)}$ Division of Veterinary Reproduction, Faculty of Veterinary Medicine, Universitas Airlangga \\ ${ }^{3,4)}$ Division of Veterinary Parasitology, Faculty of Veterinary Medicine, Universitas Airlangga \\ ${ }^{5)}$ Division of Veterinary Clinic, Faculty of Veterinary Medicine, Universitas Airlangga \\ ${ }^{6)}$ Veterinary Internal Medicine Division, Department of Clinic, Reproduction and Pathology, Faculty \\ of Veterinary Medicine, IPB University \\ Received: 15-08-2021, Accepted: 25-08-2021, Published Online: 30-09-2021 \\ Corresponding author: tjuk-i-r@fkh.unair.ac.id
}

\begin{abstract}
Abstrak
This study aims to determine the ectoparasites and endoparasites that infest fruit bats (Cynopterus brachyotis) in Ketapang Timur, Ketapang District, Sampang Regency. The samples in this study were blood, feces and ectoparasites from 50 fruit bats taken in Ketapang District, Sampang Regency. Blood samples were examined using a blood smear method with Giemsa staining, while stool samples were examined using three methods, namely native, sucrose floating, and acid-fast modification. Blood examination was checked using a microscope with 10oox magnification and stool examination at $400 x$ magnification. The sample is considered positive if under microscope observation found parasites that match the characteristics of the protozoa sourced from scientific references. The results of the study of 50 fruit bats examined found five positives for digestive protozoa and ectoparasites, the infection was single, with details of one tail being infected with Eimeria sp. and one tail was infected by Leptocyclopodia ferrarii, while blood protozoa were not found. This study concludes that the type of protozoa found in the digestive tract is Eimeria sp. (14\%) and ectoparasite Leptocyclopodia ferrarii. (2\%). The total percentage obtained was $16 \%$ positive for a single infection of protozoa and ectoparasites from 50 fruit bats. Suggestions that can be put forward are to conduct further research using PCR and sequencing to obtain more specific and accurate identification results, for subspecies or strains.
\end{abstract}

\section{Keywords: Cynopterus brachyotis, Leptocyclopodia ferrarii, Eimeria sp.}

\section{Introduction}

Wildlife acts as a major reservoir for the development of infectious and zoonotic diseases in humans and domestic animals (Daszak et al., 200o). Zoonoses originating in wildlife are known to be mostly derived from bacteria, viruses and parasites that have serious impacts on humans (Kruse et al., 2004). The existence of a population of bats also carries various diseases. Bats are wild animals that have been highlighted because they act as reservoirs for zoonotic viruses that are currently emerging such as Sars, Ebola, Marburg, Rabies, and diseases caused by paramyxoviruses such as Nipah virus and Hendra virus (Calisher et al., 2006; Damayanti and Sendow, 2015). In addition to viral diseases, many bat species are hosts to many parasites (Bertola et al., 2005). Fruit bats (family Pteropididae) are bats that eat fruit and flower products (Tan et al., 1998). Bats are also very important as pollinators and seed dispersers in tropical forests around the world (Pierson and Rainey, 1992). Bats are also social creatures that live by forming colonies and migrating. Colony density in insectivorous bat species can reach 3000 individuals $/ \mathrm{mz}$, with millions of individuals per colony (Betke et al., 2008). This activity of living in colonies and migration increases the chances of virus transmission between bat species and other animals (Luis et al., 2015). Indonesia is a country that has a high cc) (i) (2) 
potential for wildlife diversity. This diversity can be seen from the variety of wildlife species consisting of birds, mammals, reptiles, and amphibians (Hanafiah et al. 2018), with diverse fauna, one of which is from the mammal class, namely bats. Indonesia has at least 215 species of bats or $21 \%$ of the approximately 977 species of bats that are known to exist in the world (Suyanto, 2001). Based on the type of food, bats are divided into fruit eaters, insectivores, nectar eaters and blood suckers. Fruit bats (Cynopterus brachyotis) are often found in forests, namely hanging on large trees, cave walls, and on building roofs. The potential for fruit bat habitat as disease transmission is very possible with its proximity to settlements and livestock rearing systems that still use a semiintensive system. Based on the above background, the authors wish to conduct research on the identification of ectoparasites and endoparasites in fruit bats in East Ketapang Village, Sampang District. There are no data on cases of parasitic infection, both ectoparasites and endoparasites in fruit bats (C. brachyotis) in Sampang District. It is necessary to conduct research to determine endoparasites and ectoparasites in fruit bats in Ketapang Timur Village, Sampang District in order to prevent diseases involving fruit bats as reservoirs.

\section{Materials and Methods}

This research is a type of observational and descriptive survey research with the aim of knowing the type of parasite. The obtained parasites were recorded and described according to their distribution, namely in the ectoparasites and endoparasites of the blood, as well as the digestive tract.

This research was conducted from January 2021 to March 2021. Sampling of faecal endoparasites, blood and ectoparasite samples, and specimen collection were carried out in East Ketapang Village, Sampang Regency. Sample examination was carried out at the Animal Clinic Laboratory Healthy Malang. This research was conducted from April to May 2021.

The samples used in this study were feces, blood and ectoparasite specimens obtained from fruit bats (Cynopterus brachyotis) in East Ketapang Village, Sampang District. The sample size used in this study was 50 fruit bats.

Data analysis

Stool samples obtained from fruit bats (Cynopterus brachyotis) in East Ketapang Village, Sampang District were examined sequentially using the native, sedimentation and floating methods. Blood samples were examined by the blood smear method, if the examination found blood protozoa then identification of the parasite species found was carried out. The ectoparasites that were found were also identified with a morphological identification key according to Klimpel et al., (2016) and Taylor et al., (2016). The data obtained were then presented descriptively.

\section{Results and Discussion}

Identification of Protozoa in Blood, Digestive Tract and Ectoparasites. Protozoal infection and ectoparasite infection in this study were classified as single infections, namely one fruit bat was infected with one type of protozoa and one type of ectoparasite. In this study, no blood protozoa were found that infect fruit bats. Identification in this study was limited to the genus level observed under a microscope based on morphology adapted to several related books and journals. Table 1 presents the results of the examination of protozoa and ectoparasites from 50 fruit bats observed.

On examination of fruit bat feces, the protozoan found from the digestive tract of fruit bats was Eimeria sp. examination of fruit bat feces through the flotation method found oocysts of Eimeria sp. sporulated with visible sporocysts, ovoid in shape and clearly demarcated. Eimeria sp. was found in one of 50 fruit bats observed, so the prevalence of Eimeria sp. was $2 \%$ are in the category of occasional with occasional infection. The number of Eimeria sp. In one field of view there are 170 oocysts. Overview of the measurement results of Eimeria sp. 40ox magnification can be seen in Figure 1.

Table 1. The Results of fecal and ectoparasites examination of fruit bat (Cynopterus brachyotis)

\begin{tabular}{ccccc}
\hline Kind of Parasite & Number & Prevalence & Category & Sex \\
\hline Eimeria sp. & 1 & $2 \%$ & occasionally & male \\
Leptocyclopodia ferrarii. & 4 & $8 \%$ & occasionally & female \\
\hline
\end{tabular}




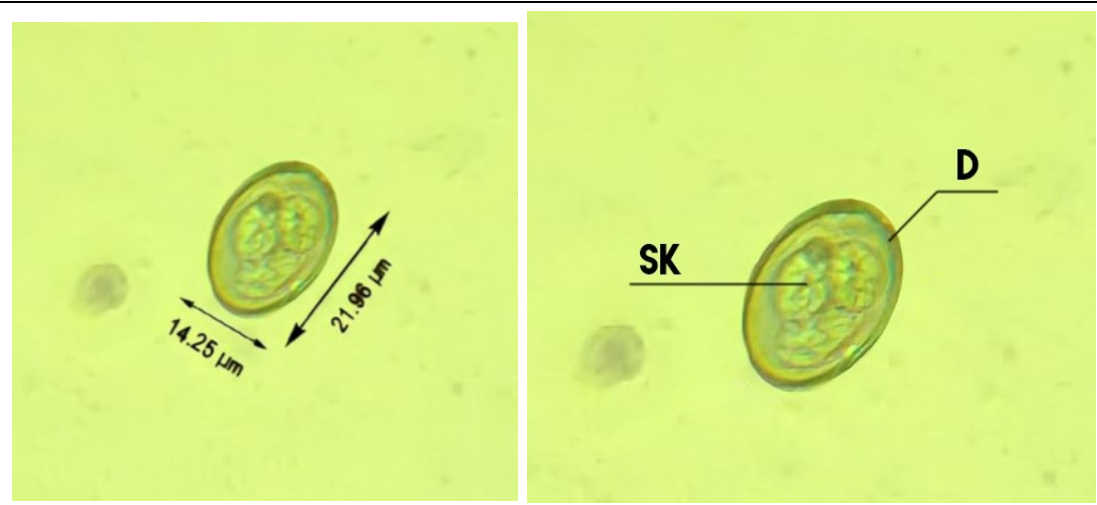

Figure 1. Eimeria sp. on microscopic examination with $400 x$ magnification in fruit bat feces samples. Note: SK (Sporocyst) and D (Oocyst wall).
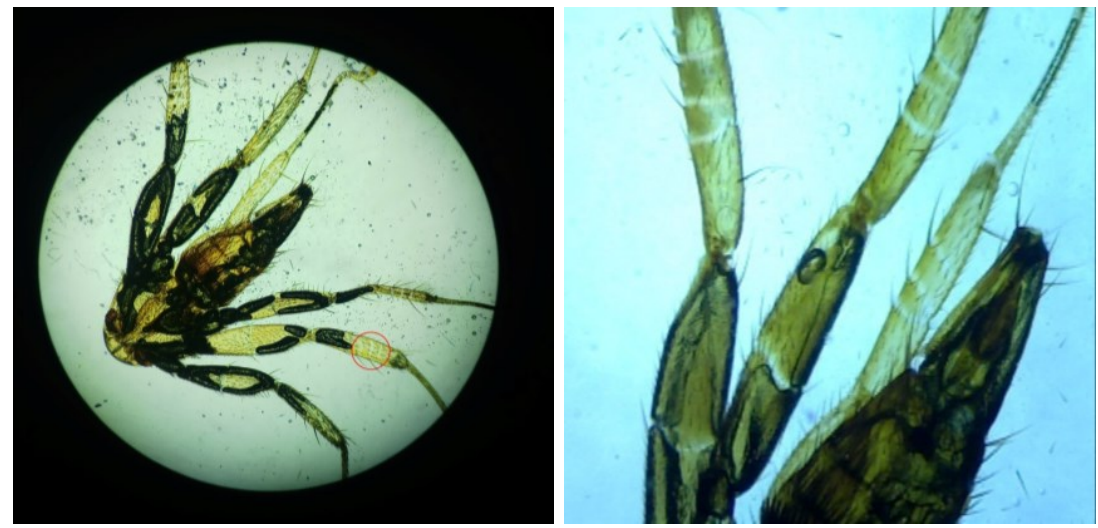

Figure 2. View of the entire body of Leptocyclopodia ferrarii at 10ox magnification. Red circle: three white stripes on the tibia.

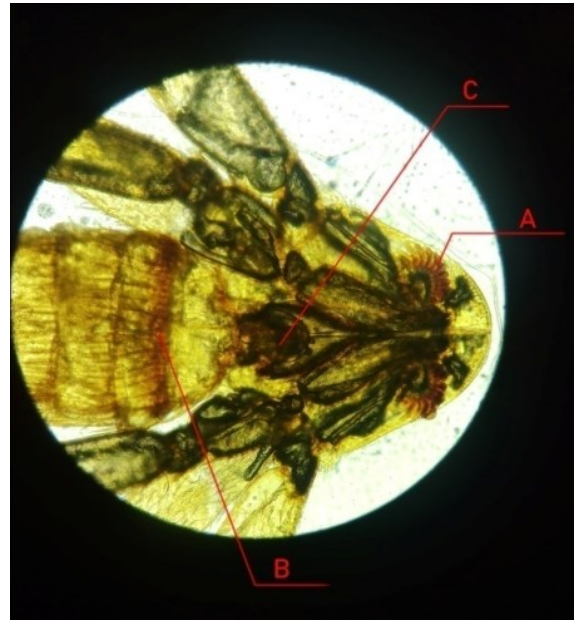

Figure 3. Morphology of Leptocyclopodia ferrarii 40ox magnification. A: Thoracic Ctenidia, B: Abdominal Ctenidia, C: Head.

On examination, the fruit bat ectoparasite found was Leptocyclopodia ferrarii. Examination of fruit bat ectoparasites through the permanent mounting method without staining found Leptocyclopodia ferrari with physical characteristics such as spiders, hairy bodies, having several ctenidia or combs, the tibia marked by three white lines and the head attached to the thorax.

Based on the results of research on 50 fruit bats taken from around the cave in East Ketapang Village, Sampang District. One fruit bat was found positive for Eimeria sp. (2\%) and four fruit bats were positive for Leptocyclopodia ferrarii (8\%). So that the number of fruit bats infected with single protozoa was five $(10 \%)$. This number is lower than the previous research which was $15 \%$ by Gay et al. (2014). In this study, no blood protozoa were found that infect fruit bats. The absence of the blood protozoa was probably due to differences in regional conditions, habitat, age, diet, and differences in behavior between species. According to Wilson and Carpenter (1996) the vulnerability of animals to parasites can be caused by, among others, captive capacity, environmental temperature, cleanliness, season, number of parasites, availability of hosts, as well as nutrition and age of the host. In several studies, bats that are often infected with blood protozoa are blood-sucking bats and insect-eating bats. This is because insects 
consumed previously have been infected by parasites, where insects are known to act as intermediate hosts or transvectors for protozoa (Adhikari, 2020). Blood-sucking bats are bats that are often indicated to be infected with blood protozoa as well as hosts and vectors for other animals, namely on the continents of South America and North America (Hoare, 1965). Blood protozoa found in bats also depend on the geographical conditions of an area whether it is an endemic area for blood protozoa or not. Spread of Eimeria sp. depending on temperature, humidity and environmental cleanliness. This research was conducted during the rainy season where the ambient temperature is low and humidity is high, so the possibility of infection with Eimeria sp. on fruit bats. Care management and environmental hygiene is not controlled because the fruit bats used are the result of wild catches. The low prevalence of Eimeria sp. related to factors such as temperature, humidity and environmental management requires a more thorough investigation of Eimeria sp. Eimeria sp. and other digestive endoparasites such as giardia and cryptosporidium are more commonly found in insectivorous bats this is reasonable because some insectivorous bats are known to prey on ground insects and spiders as food (Nowak, 1994). Insects that are consumed are usually bees, cockroaches, beetles, flies, grasshoppers, mosquitoes, moths and termites. One of these insects is a vector for worms or protozoan parasites (Adhikari et al., 2020). The most common ectoparasite found in fruit bats is Leptocyclopodia ferrarii. At first Leptocyclopodia was a subfamily of Cyclopodia which was later revised by (Maa, 1975) into a genus. Leptocyclopodia ferrarii is a specific ectoparasite that is only found in fruit bats (Olival et al., 2013). In this study, one type of ectoparasite was found in one species of fruit bat, this is in accordance with research in Singapore that Leptocyclopodia ferrarii was recorded as monoxenous, namely only one type of ectoparasite was found in one species of fruit bat (Lim et al., 2020), but in research in Malaysia is listed as oligoxenous, i.e. there is more than one type of ectoparasite in the same genus. These differences are related to the diversity and diversity of ecosystems between regions (Nangoy et al, 2021). In this study, the ectoparasite Leptocyclopodia ferrarii was found on the back of the bat's body. According to Iqbal (2014) the location of attachment of ectoparasites in bats is most commonly found on the body parts with the thickest hair, namely the back and neck. The body part with the thickest hair is a favorable habitat for ectoparasites. The location is difficult for bats to reach through grooming behavior. Thick hair provides good protection because ectoparasites can attach their bodies more strongly, so they are not affected by the movements and activities of bats (Miller, 2014). More specifically, Leptocyclopodia ferrarii in this study was found entirely in female fruit bats. The preference of Leptocyclopodia ferrarii in female fruit bats was also influenced by grooming behavior. According to Miller (2014) grooming behavior is a defense mechanism against ectoparasites. Although it is a defense mechanism, grooming behavior has some disadvantages, such as hair loss and energy drain (Hofstede et al., 2005). With limited energy, female bats generally do not perform grooming behavior because they allocate more of their energy to breastfeeding and child care activities (Piksa, 2011).

\section{Conclusions}

Based on the results of the study, it can be concluded that the types of protozoa and ectoparasites found in fruit bats are Eimeria sp. and Leptocyclopodia ferrarii. The number of fruit bats infected with Eimeria sp. as many as 1 fruit bat and the number of fruit bats infected with Leptocyclopodia ferrarii as many as 4 fruit bats.

\section{References}

Adhikari, R. B., Maharjan, M., and Ghimire, T. R. 2020. Prevalence of Gastrointestinal Parasites in the Frugivorous and the Insectivorous Batsin South central Nepal. Journal of Parasitology Research, 2020.

Bertola, P., Aires, Favorito, Graciolli, Amaku, and Pinto-da-Rocha. 2005. Bat Flies (Diptera: Streblidae, Nycteribiidae) Parasitic on Bats (Mammalia: Chiroptera) at Parque Estadual da Cantareira, Sa o Paulo, Brazil: parasitism rates and hostparasite associations. Mem Inst Oswaldo Cruz 10o(1), 25-32. doi:doi:10.1590/Soo7402762005000100005 .

Betke, M., Hirsh, D. E., Makris, N. C., McCracken, G. F., Procopio, M., Hristov, N. I., and Kunz, T. H. (2008). Thermal imaging reveals significantly smaller 
Brazilian free-tailed bat colonies than previously estimated. Journal of Mammalogy, 89(1):18-24.

Calisher, C., Childs, Field, Holmes, and Schountz, T. 2006. Bats: Important Reservoir Hosts of Emerging Viruses. Clin Microbiol Rev. 19(3):531-545.

Damayanti, N. dan Sendow, I. 2015. Ebola: Penyakit Eksotik Zoonosis yang Perlu Diwaspadai. 25(1):29-38.

Daszak, P., Cunningham, and Hyatt. 2000. Emerging Infectious Diseases of WildlifeThreats to Biodiversity and Human Health. Science 287:443-449.

Gay, N., Olival, K. J., Bumrungsri,S., Siriaroonrat,B., Bourgarel, M., and Morand,S. 2014. Parasite and viral species richness of Southeast Asian bats: fragmentation of areadistribution matters. International Journal for Parasitology: Parasites and Wildlife, 3(2):161-170.

Hanafiah, M., H. D. Alfiansyah, dan A. Sayuti. 2018. Identifikasi Parasit pada Biawak Air (Varanus salvator). Jurnal Sains Veteriner. 36(1):24-31.

Hoare, C. A. 1965 . Vampire bats as vectors and hosts of equine and bovine trypanosomes. Actatropica,22(3):204-16.

Hofstede, H.M., and Fenton, M.B. (2005). Relationships between roost preferences, ectoparasite density, and grooming behaviour of neotropical bats. Journal of Zoology,266(4):333-340.

Iqbal, H.P. 2014. Hubungan Inang-Ektoparasit Pada Kelelawar Pemakan Buah Di Kampus Universitas Indonesia, Depok.

Klimpel, S., and Mehlhorn, H. 2016. Bats (Chiroptera) as vectors of diseases and parasites. Springer-Verlag Berlin An. 25-131

Kruse, H., Kirkemo, and Handeland. 2004. Wildlife as Source of Zoonotic Infections. Emerging Infectious Diseases. 10(2):20672072.

Lim, Z. X., Hitch, A. T., Lee, B. P. H., Low, D. H., Neves, E. S., Borthwick, S. A., and Mendenhall, I. H. 2020. Ecology of bat flies in Singapore: A study on the diversity, infestation bias and host specificity (Diptera: Nycteribiidae). International
Journal for Parasitology: Parasites and Wildlife, 12:29-33.

Luis, A. D., Hayman, D. T., O'Shea, T. J., Cryan, P. M., Gilbert, A. T., Pulliam, J. R., and Webb, C. T. 2015. A comparison of bats and rodents as reservoirs of zoonotic viruses: are bats special?. Proceedings of the Royal Society B: Biological Sciences, 280(1756).

Maa,T.C. 1975. On new Diptera Pupipara from the oriental region. Pacific Insects, 16: 465486.

Miller, C. 2014. Host specificity and ectoparasite load of batflies in Utila, Honduras.

Nangoy, M., Ransaleleh, T., Lengkong, H., Koneri, R., Latinne, A., and Kyes, R.C. 2021. Diversity of fruit bats (Pteropodidae) and their ectoparasites in Batuputih Nature Tourism Park, Sulawesi, Indonesia. Biodiversitas Journal of Biological Diversity, 22(6).

Nowak, R.M., and Walker, E.P. 1994. Walker's bats of the world. JHU Press.

Olival, K. J., Dick, C. W., Simmons, N. B., Morales, J. C., Melnick, D. J., Dittmar, K., and DeSalle,R. 2013. Lack of population genetic structure and host specificity in the batfly, Cyclopodia horsfieldi, across species of Pteropus bats in Southeast Asia. Parasites \&Vectors,6(1):1-18.

Pierson, E., and Rainey. 1992. The Biology of Flying Foxes of the Genus Pteropus: a review. In: Pacific Island Flying Foxes: Proceedings of an International Conservation Conference (eds. D.E. Wilson and G.L. Graham). 1-17.

Piksa, K., Skwarek, M., and Siuda, K. 2011. Argasid and spinturnicid mite load on swarming bats in the Tatra mountains, Poland. Folia parasitologica, 58(4),322.

Suyanto, A. 2001. Kelelawar di Indonesia. Cetakan Pertama.Puslitbang Biologi LIPI. Bogor.

Tan, K., Zubaid, and Kunz. 1998. Food Habits of Cynopterus brachyotis (Muller) (Chiroptera: Pteropodidae) in Peninsular Malaysia. Journal of Tropical Ecology. 14: 299-307. 
Taylor, M., Coop,, and Wall. 2016. Veterinary Parasitology. $4^{\text {th }}$ Edition. Blackwell Publishing. UK. 853-886.
Wilson, S. C., and Carpenter, J. W. 1996. Endoparasitic diseases of reptiles. In Seminars in Avian and Exotic Pet Medicine Vol. 2, No. 5:64-74. 